\title{
Article \\ Evidence for the Involvement of Pleckstrin Homology Domain-Containing Proteins in the Transport of Enterocin DD14 (EntDD14); a Leaderless Two-Peptide Bacteriocin
}

\author{
Adrián Pérez-Ramos ${ }^{1}$, Rabia Ladjouzi ${ }^{1} \mathbb{D}$, Abdellah Benachour $^{2} \mathbb{D}$ and Djamel Drider ${ }^{1, * \mathbb{D}}$ \\ 1 UMR Transfrontalière BioEcoAgro 1158, University Lille, INRAE, University Liège, UPJV, YNCREA, \\ University Artois, University Littoral Côte d'Opale, ICV—Institut Charles Viollette, 59000 Lille, France; \\ adrian.perez-ramos@univ-lille.fr (A.P.-R.); rabia.ladjouzi@univ-lille.fr (R.L.) \\ 2 UR Risques Microbiens, Normandie University, UNICAEN, U2RM, 14000 Caen, France; \\ abdellah.benachour@unicaen.Fr \\ * Correspondence: djamel.drider@univ-lille.fr
}

check for updates

Citation: Pérez-Ramos, A.; Ladjouzi, R.; Benachour, A.; Drider, D. Evidence for the Involvement of Pleckstrin Homology Domain-Containing Proteins in the Transport of Enterocin DD14 (EntDD14); a Leaderless Two-Peptide Bacteriocin. Int. J. Mol. Sci. 2021, 22, 12877. https://doi.org/ $10.3390 /$ ijms222312877

Academic Editor: Andreas Burkovski

Received: 29 September 2021

Accepted: 25 November 2021

Published: 28 November 2021

Publisher's Note: MDPI stays neutral with regard to jurisdictional claims in published maps and institutional affiliations.

Copyright: (C) 2021 by the authors Licensee MDPI, Basel, Switzerland This article is an open access article distributed under the terms and conditions of the Creative Commons Attribution (CC BY) license (https:// creativecommons.org/licenses/by/ $4.0 /)$

\begin{abstract}
Bacteriocins synthesis is initiated from an inactive precursor, which is composed of an Nterminal leader peptide attached to a C-terminal pro-peptide. However, leaderless bacteriocins (LLB) do not possess this N-terminal leader peptide nor undergo post-translational modifications. These atypical bacteriocins are observed to be immediately active after their translation in the cytoplasm. However, although considered to be simple, the biosynthetic pathway of LLB remains to be fully understood. Enterocin DD14 (EntDD14) is a two-peptide LLB produced by Enterococcus faecalis 14, which is a strain isolated from meconium. In silico analysis of DNA encoding EntDD14 located a cluster of 10 genes $d d A B C D E F G H I J$, where $d d E$ and $d d F$ encode the peculiar DdE and DdF proteins, carrying pleckstrin homology $(\mathrm{PH})$ domains. These modules are quite common in Eucarya proteins and are known to be involved in intracellular signaling or cytoskeleton organization. To elucidate their role within the EntDD14 genetic determinants, we constructed deletion mutants of the $d d E$ and $d d F$ genes. As a result, the mutants were unable to export EntDD14 outside of the cytoplasm even though there was a clear expression of structural genes $d d A B$ encoding EntDD14, and genes $d d H I J$ encoding an $\mathrm{ABC}$ transporter. Importantly, in these mutant strains ( $\triangle d d E$ and $\Delta d d F$ ), EntDD14 was detected by mass spectrometry in the intracellular soluble fraction exerting, upon its accumulation, a toxic effect on the producing strain as revealed by cell-counting and confocal microscopy analysis. Taken together, these results clearly indicate that $\mathrm{PH}$ domain-containing proteins, such as DdE and DdF, are involved in the transport of the leaderless two-peptide EntDD14.
\end{abstract}

Keywords: leaderless bacteriocins; EntDD14; pleckstrin homology domain; bacteriocin transport

\section{Introduction}

Bacteriocins are produced by a wide range of Gram-negative bacteria (GNB), Grampositive bacteria (GPB), and Archaea [1-3], permitting them to compete with congeners and thrive in their ecological niches. Of note, bacteriocins produced by GNB (named microcins), and those produced by GPB have been intensively studied and have shown similarities in their biosynthetic pathways and differences in their modes of action [4,5].

Due to the increasing number of bacteriocins discovered, their classification is regularly revised and updated. The most recent revision proposes the inclusion of bacteriocins from both GPB and GNB into two main classes [6]. Briefly, class I contains bacteriocins with a molecular weight of less than $5 \mathrm{kDa}$ and undergoing post-translational modifications (PTMs), while class II comprises principally unmodified bacteriocins of 6-10 kDa, including or not stabilizing disulfide bridges [6].

Bacteriocins are known to be synthesized as inactive pre-peptides that undergo a maturation process, proceeding to fully active peptides. Notably, the precursor peptide 
carries an N-terminal leader region and C-terminal core region, which is subjected to enzymatic PTMs, leading therefore to ribosomally synthesized and post-translationally modified peptides (RiPPs) [7]. The leader peptide is often cut off at a double-glycine proteolytic processing site during export by an ATP-binding cassette (ABC) transporter, and the mature peptide is released into the external environment. The cleavage of the leader peptide can be performed by the same ABC transporter (SunT-type transporter) or by an associated protein (NisT-type) [5,8]. However, other bacteriocins, such as enterocin $\mathrm{P}$, contain an $\mathrm{N}$-terminal sec-dependent sequence leader and follow another secretory pathway, being secreted by general sec-dependent export systems [9]. Furthermore, there are bacteriocins with leader peptide whose transport systems remain to be determined [8].

The export of bacteriocins is tightly associated with a complex immunity machinery, since the bacteriocin-producing bacteria need to protect themselves from the toxicity of their own bacteriocins. This immunity can be exerted by dedicated proteins and/or ABC transporters [10]. This is the case of NisEFG for nisin [11] or As-48EFGH for the cyclic enterocin AS-48 [12].

Cintas et al. [13] reported that enterocin L50, previously classified as a pediocin-like bacteriocin, was actually composed of two peptides, L50A/B, which was transported without any processing, leading to the emergence of the leaderless bacteriocins (LLB) group. These atypical bacteriocins do not undergo any PTM or processing and are thought to be active immediately after their translation [14]. Although LLB have no leader peptide for their export, they are also transported by $\mathrm{ABC}$ transporters. For instance, aureocin A70 is thought to be externalized by a single-component $A B C$ transporter AurT [15]. Whereas a three-component $\mathrm{ABC}$ transporter is involved in both transport and immunity to LLB aureocin A53 [16], this transporter is not the only pathway, because when removed, there is still bacteriocin externalization. Therefore, the uncharacterized Orf8 protein has been reported to be essential for LLB aureocin A53 transport [16].

EntDD14 is a two-peptide LLB produced by Enterococcus faecalis 14 isolated from meconium [17,18], and its activity is essentially directed against GPB including Clostridium perfringens, Listeria, and other enterococcal strains [18]. The two peptides of EntDD14 (EntDD14A/B) are 100\% identical to those of MR10 [19] and Ent7 [20] enterocins and 98\% and 95\% identical to those of L50A/B [13], respectively. Recent studies on EntDD14 showed that deletion of the ATP-binding protein component of the putative ABC transporter reduced the bacteriocin externalization by about $75 \%$, and this $A B C$ transporter is not involved in any bacterial self-immunity system to our current knowledge [21].

In silico analysis of the EntDD14 operon has revealed two proteins, named DdE and $\mathrm{DdF}$, which carry pleckstrin homology $(\mathrm{PH})$ domains. Of note, the $d d E$ and $d d F$ genes are located upstream of those encoding the $\mathrm{ABC}$ transporter $d d \mathrm{HIJ}$. The $\mathrm{PH}$ domain is abundant in Eukarya, where it is associated with diverse functions, such as intracellular signaling and cytoskeletal organization [22,23]. The presence of the PH domain module in bacterial proteins was discovered by $\mathrm{Xu}$ et al. [24], who reported the bacterial PH domains, $\mathrm{PH} b 1$ and $\mathrm{PH} b 2$. Interestingly, the in silico analysis undertaken for this work showed that the DdE and DdF proteins may contain one or more PHb2 domains. Remarkably, the deletion of $d d E$ or $d d F$ genes encoding the DdE or DdF protein, which carry the PH domain, led to a very interesting result; namely, following the deletion of $d d E$ or $d d F$, the two-peptide LLB EntDD14 was no longer externalized, and its intracellular accumulation exerted a toxic effect on the bacteriocin-producing bacteria.

\section{Results}

\subsection{In Silico Characterization of DdE and DdF Proteins}

The EntDD14 cluster is composed of 10 genes: $d d A B C D E F G H I J$. Genes $d d A B$ encode the two peptides of EntDD14, while ddHIJ encode the ABC transporter [21]. The other remaining five genes, $d d C D E F G$, were allocated to proteins of unknown functions. Of note, genes $d d E F$, which encode two proteins of 141 (DdE) and 458 (DdF) amino acid residues, displayed homology with proteins carrying PH domains. The BLAST tool analysis revealed 
the presence of the conserved protein domain family YdbT (Genbank accession COG3428), within the primary structure of the DdF protein. Remarkably, this domain is based on the uncharacterized membrane protein $\mathrm{YdbT}$, which contains the $\mathrm{PH} b 2$ (bacterial pleckstrin homology) domain that was first described in Bacillus subtilis. In the genome of B. subtilis ssp. subtilis 168 strain, the protein YdbT of 493 amino acid residues is associated to heterologous antibiotic resistance (Genbank accession NP_388341.1), although no experimental evidence supported the allocation of such a function. Upstream of YdbT, we detected another PH domain containing the protein named YdbS, of 159 amino acids, which has the conserved protein domain family YdbS (Genbank accession COG3402). The reported data from the Protein Data Bank (PDB) revealed that YdbS protein has two transmembrane (TM) domains and one PHb2 domain, while the YdbT protein has six TM domains and three $\mathrm{PH} b 2$ domains (Figure 1A).
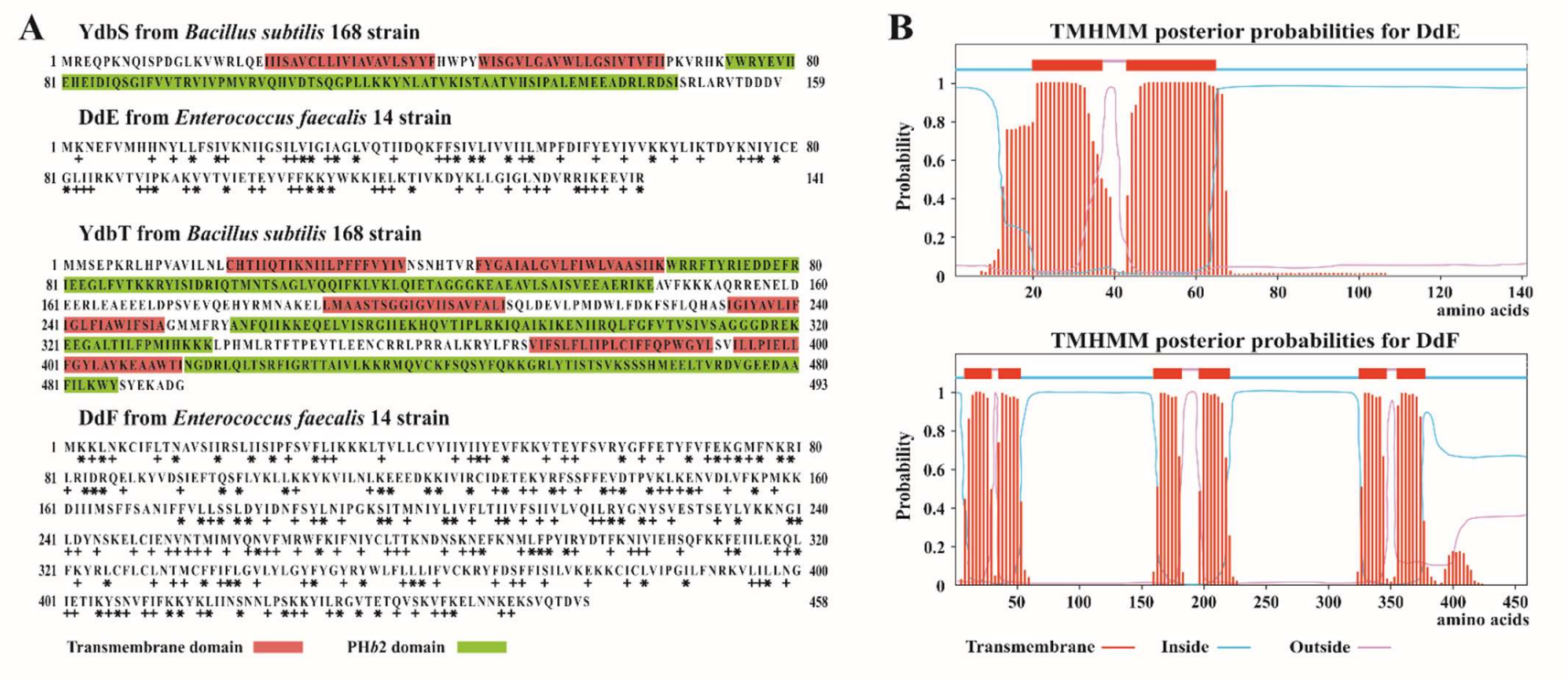

Figure 1. (A) Amino acid sequences of the YdbS and YdbT proteins, where their transmembrane and PHb2 domains are highlighted (data taken from PDB). In addition, amino acids sequences of DdE and DdF proteins are depicted showing their identical $\left(^{*}\right)$ and positive $(+)$ amino acid residues when aligned with YdbS and YdbT, respectively. (B) Transmembrane domains predicted for the DdE and DdF proteins.

Of note, genes encoding homologous proteins of $\mathrm{YdbT}$ and $\mathrm{YdbS}$ were detected in the genomes of bacteria such as Staphylococcus aureus, Corynebacterium glutamicum, or L. innocua (Table 1). In all these species, the two genes encoding YdbS- and YdbT-like proteins are contained in a same locus exhibiting a common transcriptional orientation, as is the case of $d d E$ and $d d F$ genes. Furthermore, DdE and DdF proteins share sequence homology with $B$. subtilis YdbS and YdbT, respectively, although they are only $17 \%$ and $18 \%$ identical (Table 1 and Figure 1A).

According to BLAST analyses in the E. faecium L50 strain, which produces the leaderless two-peptide enterocin L50, counterparts of the DdE and DdF proteins exist, and they displayed $79 \%$ and $74 \%$ of identity to those found in the EntDD14 operon. Moreover, the counterparts of these proteins were found in other enterococci strains, which have homologous EntDD14 clusters, as reported in our previous study [21]. 
Table 1. Members of the bacterial proteins families YdbS and YdbT containing $\mathrm{PH} b 2$ domains from Bacillus subtilis ssp. subtilis 168 .

\begin{tabular}{|c|c|c|c|c|c|c|}
\hline Protein & Size $^{a}$ & Accession No & $\% I^{b}$ & $\% P^{c}$ & Bacteria & Accession No \\
\hline$Y_{d b S}^{d}$ & 159 & NP_388340.1 & 100 & 100 & $\begin{array}{l}\text { Bacillus subtilis ssp. } \\
\quad \text { subtilis } 168\end{array}$ & NC_000964.3 \\
\hline YdbS & 159 & VEH76774.1 & 68 & 79 & $\begin{array}{l}\text { Bacillus licheniformis } \\
\text { NCTC10341 }\end{array}$ & LR134392.1 \\
\hline Lin0881 & 160 & WP_003761286.1 & 40 & 58 & Listeria innocua Clip11262 & NC_003212.1 \\
\hline SA1878 & 159 & WP_001287087.1 & 23 & 43 & $\begin{array}{c}\text { Staphylococcus aureus ssp. } \\
\text { aureus N315 }\end{array}$ & NC_002745.2 \\
\hline NCgl0612 & 149 & WP_003860754.1 & 24 & 47 & $\begin{array}{c}\text { Corynebacterium } \\
\text { glutamicum ATCC } 13032\end{array}$ & NC_003450.3 \\
\hline MT_RS06490 & 177 & WP_003406264.1 & 25 & 48 & $\begin{array}{c}\text { Mycobacterium tuberculosis } \\
\text { CDC1551 }\end{array}$ & NC_002755.2 \\
\hline DdE & 141 & - & 17 & 47 & Enterococcus faecalis 14 & СР021161.1 \\
\hline$Y d b T^{d}$ & 493 & NP_388341.1 & 100 & 100 & $\begin{array}{l}\text { Bacillus subtilis ssp. } \\
\quad \text { subtilis } 168\end{array}$ & NC_000964.3 \\
\hline YdbT & 493 & VEH76775.1 & 52 & 72 & $\begin{array}{l}\text { Bacillus licheniformis } \\
\text { NCTC10341 }\end{array}$ & LR134392.1 \\
\hline Lin0882 & 494 & WP_010990663.1 & 31 & 51 & Listeria innocua Clip11262 & NC_003212.1 \\
\hline SA1877 & 527 & WP_001294626.1 & 23 & 46 & $\begin{array}{c}\text { Staphylococcus aureus ssp. } \\
\text { aureus N315 }\end{array}$ & NC_002745.2 \\
\hline NCgl0613 & 471 & WP_011013786.1 & 17 & 45 & $\begin{array}{c}\text { Corynebacterium } \\
\text { glutamicum ATCC } 13032\end{array}$ & NC_003450.3 \\
\hline MT_RS06485 & 487 & WP_003898781.1 & 17 & 38 & $\begin{array}{c}\text { Mycobacterium tuberculosis } \\
\text { CDC1551 }\end{array}$ & NC_002755.2 \\
\hline $\mathrm{DdF}$ & 458 & - & 18 & 44 & Enterococcus faecalis 14 & СР021161.1 \\
\hline
\end{tabular}

${ }^{a}$ The protein size is given in number of amino acid residues. ${ }^{b}$ Percentage of identical homology compared with the template $B$. subtilis $168 \mathrm{YdbS}$ or YdbT proteins. ${ }^{\mathrm{c}}$ Percentage of positive homology compared with the template B. subtilis $168 \mathrm{YdbS}$ or YdbT proteins. ${ }^{\mathrm{d}}$ Model proteins used as template for the homology analysis.

To gain more insights on DdE and DdF, we analyzed in silico their secondary structure and TM domains prediction. This analysis supports the membrane localization of these proteins. Indeed, DdE contains two TM domains, whereas DdF contains six TM domains (Figure 1B), and they seem to have similar structural organization such as YdbS and YdbT proteins of B. subtilis (Figure 1A). In addition, the amino acid sequences of DdE and DdF were analyzed using the I-Tasser program that utilizes the resolved 3D structure of proteins deposited in the Protein Data Bank $[25,26]$. Given the homology between the amino acid sequences and the number and arrangement of TM domains, we assume that the DdE and DdF proteins could contain one and three $\mathrm{PH} b 2$ domains, respectively. These $\mathrm{PH} b 2$ domains, which are composed of 72-80 amino acids, are cytosolically oriented. The I-Tasser program predicts the secondary structure in terms of $\alpha$-helix, $\beta$-sheet, and coil. Therefore, the $\mathrm{PH} b 2$ domains of DdF were shown to be rich in $\beta$-sheets $(\approx 58 \%)$, while that of DdE contained of $\approx 41 \% \beta$-sheet (Table 2). 
Table 2. Prediction of the secondary structure of DdE and DdF PHb2 domains.

\begin{tabular}{cccccc}
\hline Protein & PH $b 2$ Domain & Size $^{\mathbf{a}}$ & \% $\beta$-Sheet & \% $\boldsymbol{\alpha}$-Helix & \% Coil \\
\hline DdE & $67-138$ & 72 & 41.67 & 43.05 & 15.28 \\
\hline \multirow{3}{*}{ DdF } & $54-133$ & 80 & 57.50 & 13.75 & 28.75 \\
& $222-295$ & 74 & 58.11 & 13.51 & 28.38 \\
& $382-453$ & 72 & 58.33 & 25.00 & 16.67 \\
\hline
\end{tabular}

a The protein size is given in number of amino acid residues.

Furthermore, the I-Taser program has identified several proteins whose 3D structures are significantly similar to those of DdE and DdF. Of note, all these identified proteins are found to be involved in the membrane transport and translocation mechanisms (Table 3). Interestingly, this in silico analysis underpinned a strong homology between the DdE structure and that of the ABC transporter PCAT1 from Hungateiclostridium thermocellum. Taken together, these results suggest that the DdE and DdF proteins are membrane proteins that may be involved in the transport of EntDD14.

Table 3. Proteins structurally close to DdE and DdF obtained with the I-TASSER program.

\begin{tabular}{|c|c|c|c|c|c|}
\hline PDB & TM-Score $^{a}$ & Characteristic & Role & Organism & Reference \\
\hline \multicolumn{6}{|c|}{ DdE structurally close proteins } \\
\hline $6 \mathrm{fok}$ & 0.538 & $\begin{array}{l}\text { Respiratory alternative } \\
\text { complex III }\end{array}$ & $\begin{array}{l}\text { Electron transfer } \\
\text { membrane protein }\end{array}$ & $\begin{array}{l}\text { Rhodothermus marinus } \\
\text { DSM } 4252\end{array}$ & [27] \\
\hline $6 \mathrm{btm}$ & 0.533 & $\begin{array}{l}\text { Respiratory alternative } \\
\text { complex III }\end{array}$ & $\begin{array}{l}\text { Electron transfer } \\
\text { membrane protein }\end{array}$ & $\begin{array}{l}\text { Flavobacterium johnsoniae } \\
\text { UW101 }\end{array}$ & [28] \\
\hline $3 \mathrm{e} 0 \mathrm{~s}$ & 0.521 & Uncharacterized protein & $\begin{array}{c}\text { Structural } \\
\text { genomics/unknown } \\
\text { function }\end{array}$ & Chlorobaculum tepidum & unpublished \\
\hline 3jrt & 0.518 & $\begin{array}{l}\text { Integron cassette protein } \\
\text { Vpc_cass2 }\end{array}$ & $\begin{array}{c}\text { Structural } \\
\text { genomics/unknown } \\
\text { function }\end{array}$ & Vibrio paracholerae & [29] \\
\hline $7 \mathrm{~d} 3 \mathrm{e}$ & 0.511 & $\begin{array}{l}\text { DUOX1-DUOXA1 in } \\
\text { low-calcium state }\end{array}$ & Electron transport & Homo sapiens & unpublished \\
\hline $5 u 6 o$ & 0.507 & $\begin{array}{c}\text { HCN1 } \\
\text { hyperpolarization-activated } \\
\text { cyclic nucleotide-gated ion } \\
\text { channel }\end{array}$ & Transport protein & Homo sapiens & [30] \\
\hline \multicolumn{6}{|c|}{ DdF structurally close proteins } \\
\hline 4ry2 & 0.712 & $\begin{array}{l}\text { Peptidase-containing ABC } \\
\text { transporter PCAT1 }\end{array}$ & $\begin{array}{c}\text { Transport } \\
\text { protein/hydrolase }\end{array}$ & $\begin{array}{c}\text { Hungateiclostridium } \\
\text { thermocellum ATCC } 27405\end{array}$ & [31] \\
\hline $3 q f 4$ & 0.434 & $\begin{array}{l}\text { Heterodimeric } \mathrm{ABC} \\
\text { transporter }\end{array}$ & Transport protein & Thermotoga maritima & [32] \\
\hline $4 \mathrm{mrn}$ & 0.433 & $\begin{array}{l}\text { Bacterial Atm1-family } \mathrm{ABC} \\
\text { transporter }\end{array}$ & Transport protein & $\begin{array}{c}\text { Novosphingobium } \\
\text { aromaticivorans DSM } \\
12444\end{array}$ & [33] \\
\hline $3 f f z$ & 0.423 & $\begin{array}{c}\text { Domain organization in } \\
\text { butulinum neurotoxin type E }\end{array}$ & Hydrolase/translocation & Clostridium botulinum & [34] \\
\hline 6tqe & 0.413 & $\mathrm{ABC}$ transporter Rv1819c & Transport protein & Mycobacterium tuberculosis & [35] \\
\hline $5 \mathrm{mkk1}$ & 0.407 & $\begin{array}{l}\text { Heterodimeric } \mathrm{ABC} \\
\text { transporter TmrAB }\end{array}$ & Transport protein & $\begin{array}{c}\text { Thermus thermophilus } \\
\text { HB27 }\end{array}$ & [36] \\
\hline
\end{tabular}

${ }^{\mathrm{a}} \mathrm{TM}$ score assesses the topological similarity of protein structures. Values are between 0 and 1 . A score higher than 0.5 indicates generally the same fold in SCOP/CATH.

\subsection{PH Domain-Containing Proteins DdE and DdF Are Essential for EntDD14 Transport}

To confirm our in silico analyses, we deleted genes encoding DdE or DdF and analyzed the resulting phenotype of the mutant strains. The deletion of each gene was performed by homologous recombination, using the thermosensitive vector pLT06 [37]. Of note, 


\begin{abstract}
E. faecalis $14 \Delta d d E$ and $\Delta d d F$ mutant strains were obtained, and their genetic backgrounds were confirmed by PCR and sequence analyses. Antibacterial assessment of cell-free supernatant (CFS) from $\Delta d d E$ or $\Delta d d F$ mutants was performed by the well-known agar diffusion test (ADT) against Listeria innocua ATCC33090 as the bacterial target. Importantly, no inhibitory activity was detected, arguing the absence of EntDD14 in the CFS of the mutant strains (Figure 2A). Therefore, each independently deleted gene entailed the total loss of antimicrobial activity. To confirm this hypothesis, MALDI-TOF/MS analysis was applied on CFS gathered from each mutant strain as well as from the wild type (WT). As expected, EntDD14 was not detected in the CFS from mutant strains (Figure 2B); conversely, that from the WT exhibited a typical peak of $5.2 \mathrm{kDa}$, corresponding to that of EntDD14, as previously reported by Caly et al. [18].
\end{abstract}
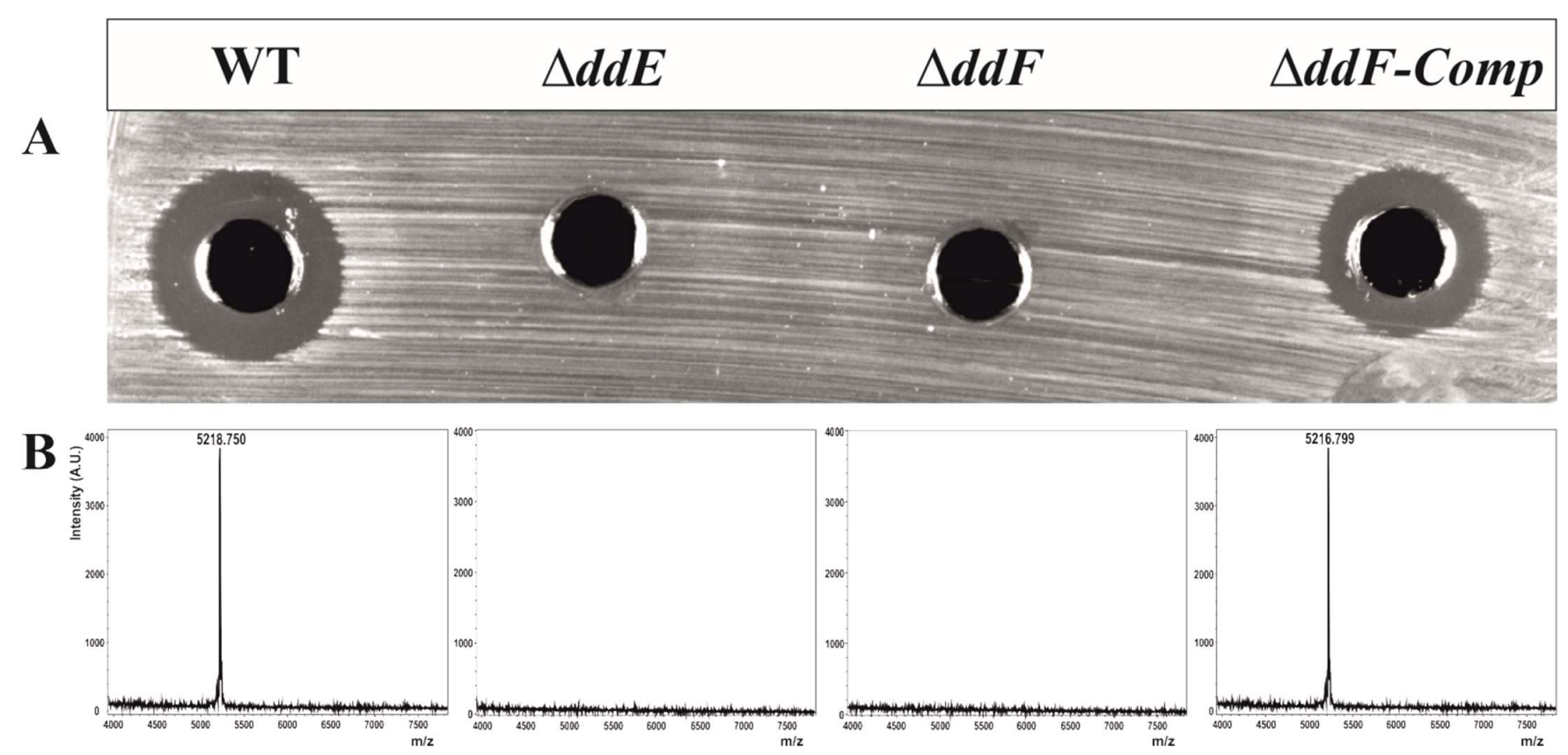

Figure 2. Production of the EntDD14 by E. faecalis 14 WT and its derivative mutant strains. (A) Agar diffusion test of cell-free supernatants against L. innocua ATCC 33090. The inhibition halo indicates DD14 production. (B) Detection of the EntDD14 purified from bacterial supernatants by matrix-assisted laser desorption ionization time-of-flight mass spectrometry (MALDI-TOF/MS).

These independent ways of investigation enabled us to claim that the abolition of DdE or DdF activity impedes transport from the cytoplasm of EntDD14. To strengthen this statement, trans-complementation assays were conducted upon cloning the $d d F$ gene into the Gram-positive replicative plasmid pAT18 [38]. The E. faecalis $\Delta d d F$-complemented strain was generated in the presence of erythromycin. However, the presence of the antibiotic is not compatible with the antimicrobial assay. A study of plasmid stability showed that after 10 and 30 generations without selection pressure, the number of bacteria still harboring the pAT18: $d d F$ recombinant vector was $95 \%$ and $89 \%$, respectively (data not shown). Thus, we performed all the assays with the complemented strain without erythromycin selection. Following this, the $\Delta d d F$-complemented strain was able to secrete again EntDD14, as confirmed by the ADT (Figure 2A) and MALDI-TOF/MS analyses (Figure 2B).

These genetic experimental data showing that $E$. faecalis 14 lacking DdE or DdF protein is clearly unable to transport or translocate out of the cytoplasm EntDD14 bacteriocin reinforce the predictions of the in silico analysis that allocated them a key role in the transport machinery. This surprising result suggests a new pathway in the mode of transport involving PH domain-containing proteins and likely also in the mode of action of the leaderless two-peptide EntDD14. 


\subsection{Loss of DdE or DdF Protein Leads to Overexpression of the EntDD14 Operon}

To gain further insight into the EntDD14 mode of transport, a transcriptional analysis was carried out to evaluate the expression of genes involved in the production and transport of EntDD14, primarily those supposed to constitute the ABC transporter (ddHIJ). This gene expression experiment was conducted after $5 \mathrm{~h}$ (end of logarithmic phase) and $24 \mathrm{~h}$ (stationary phase) of growth of the WT strain and its isogenic derivatives $\Delta d d E$ and $\Delta d d F$ mutant strains, and the results are shown in Figure 3.

A

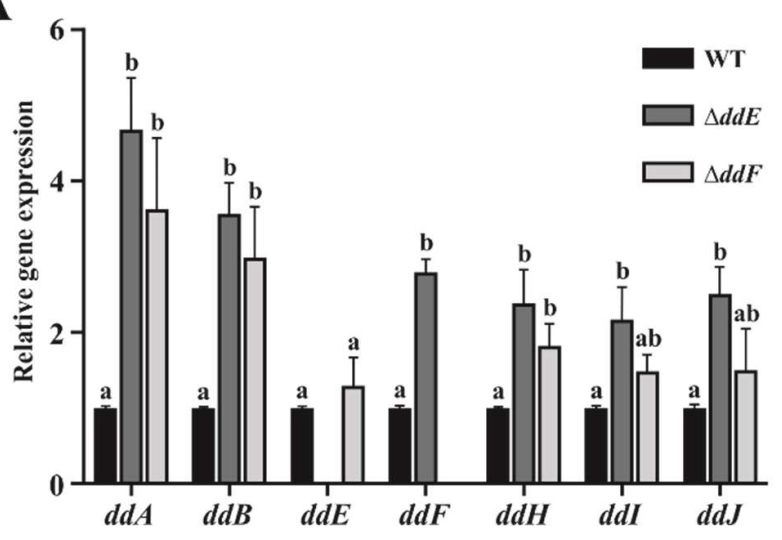

B

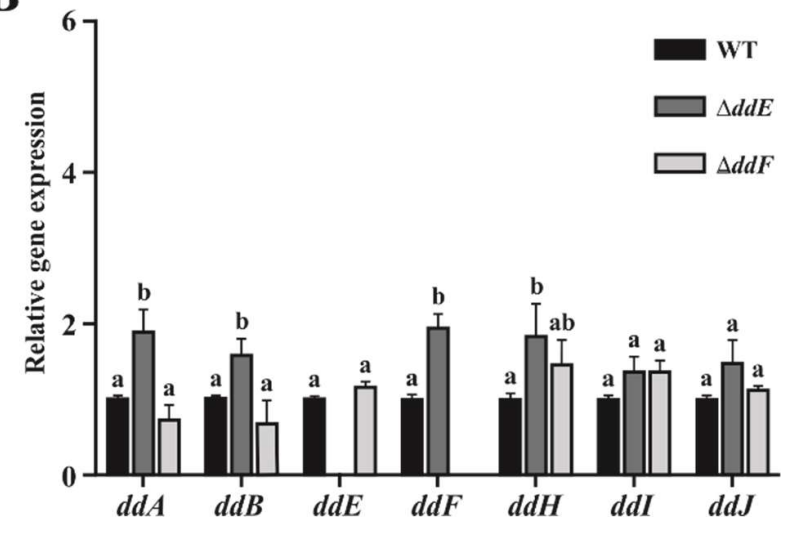

Figure 3. Relative expression values of $d d A B E F H I J$ genes in $\triangle d d E$ and $\triangle d d F$ mutant strains compared to the WT strain at $5 \mathrm{~h}$ (A) and $24 \mathrm{~h}$ (B) of bacterial growth. The gyrase gene was used as an internal standard to normalize the values. Statistical significances are represented by letters $\mathrm{a}$ and $\mathrm{b}$, which mean $p<0.05$.

Regarding these results, all the genes tested are constitutively expressed by the WT strain both at the end of the exponential phase and in the stationary phase ( $24 \mathrm{~h})$. This means that the WT strain is accustomed to tolerating the presence of EntDD14 at a level that does not interfere with its growth or development. In other words, the WT strain must have an intrinsic level of resistance or immunity to its own bacteriocin that may be due to the balance between the production and evacuation of the enterocin, as reflected in the expression of the genes constituting its operon structure.

Indeed, when this expression balance is disrupted by turning off either of the $d d E$ or $d d F$ genes, the resulting mutants react differently from the WT, and we observe more disturbance at the end of the exponential phase (Figure 3A) than in the stationary phase (Figure 3B), but the changes go in the same direction in the two cases.

At the end of the log phase, $d d A$ and $d d B$ genes were 4.6- and 3.5-fold overexpressed in the $\triangle d d E$ mutant and 3.6- and 3-fold overexpressed in the $\triangle d d F$ mutant (Figure 3A). For both situations, the overexpression of $d d A$ and $d d B$ genes suggests that they may be influenced by the $d d E$ and $d d F$ genes, which could lead, in their corresponding mutants, to an overproduction of EntDD14. Among the genes involved in its extracellular export, mainly $d d F$ of the $\triangle d d E$ mutant is clearly overexpressed (2.7-folds) but at a lower level than for the structural $d d A$ and $d d B$ genes, which suggests an additional deficit in the ability to evacuate the enterocin outside the cell. As for the other genes of the $A B C$ transporter system $(d d H I J)$, they are overexpressed by a factor of about 2 and mainly in the $\triangle d d E$ mutant.

This situation occurs also at the stationary phase but with lower overexpression levels and only for the $\triangle d d E$ mutant, since there is even a slight downexpression of $d d A B$ genes in $\triangle d d F$ mutant (Figure $3 \mathrm{~B}$ ), and this may be due to the much-reduced metabolic activity.

These data indicate overall that (i) $d d A B$ genes and (ii) those coding for $A B C$ transporter are expressed in the mutant strains deprived of DdE and DdF proteins, but the cells are unable to externalize EntDD14 outside of the cytoplasm, allowing EntDD14 to accumulate inside the cells. To investigate this point, total intracellular proteins extracted from $\Delta d d E$ or $\triangle d d F$ mutant strains were analyzed by MALDI-TOF/MS and compared to those extracted from the WT and the $\Delta b a c$ mutant strain, which were formerly obtained by 
knocking-out $d d A B$ genes and characterized for their inability to produce EntDD14 [21]. In both $\triangle d d E$ and $\triangle d d F$ mutant strains, a peak corresponding to EntDD14 with a molecular size of $5.2 \mathrm{kDa}$ was detected (Figures $4 \mathrm{C}$ and $4 \mathrm{D}$, respectively). Of note, this peak was also detected in the WT but not in the $\Delta b a c$ mutant strain (Figures $4 \mathrm{~A}$ and $4 \mathrm{~B}$, respectively). Nevertheless, the intensity of the peaks was 400 AU for WT, 1800 AU for $\Delta d d E$, and $1600 \mathrm{AU}$ for $\Delta d d F$, suggesting an elevated presence of intracellular EntDD14 in the derivative-mutant strains.

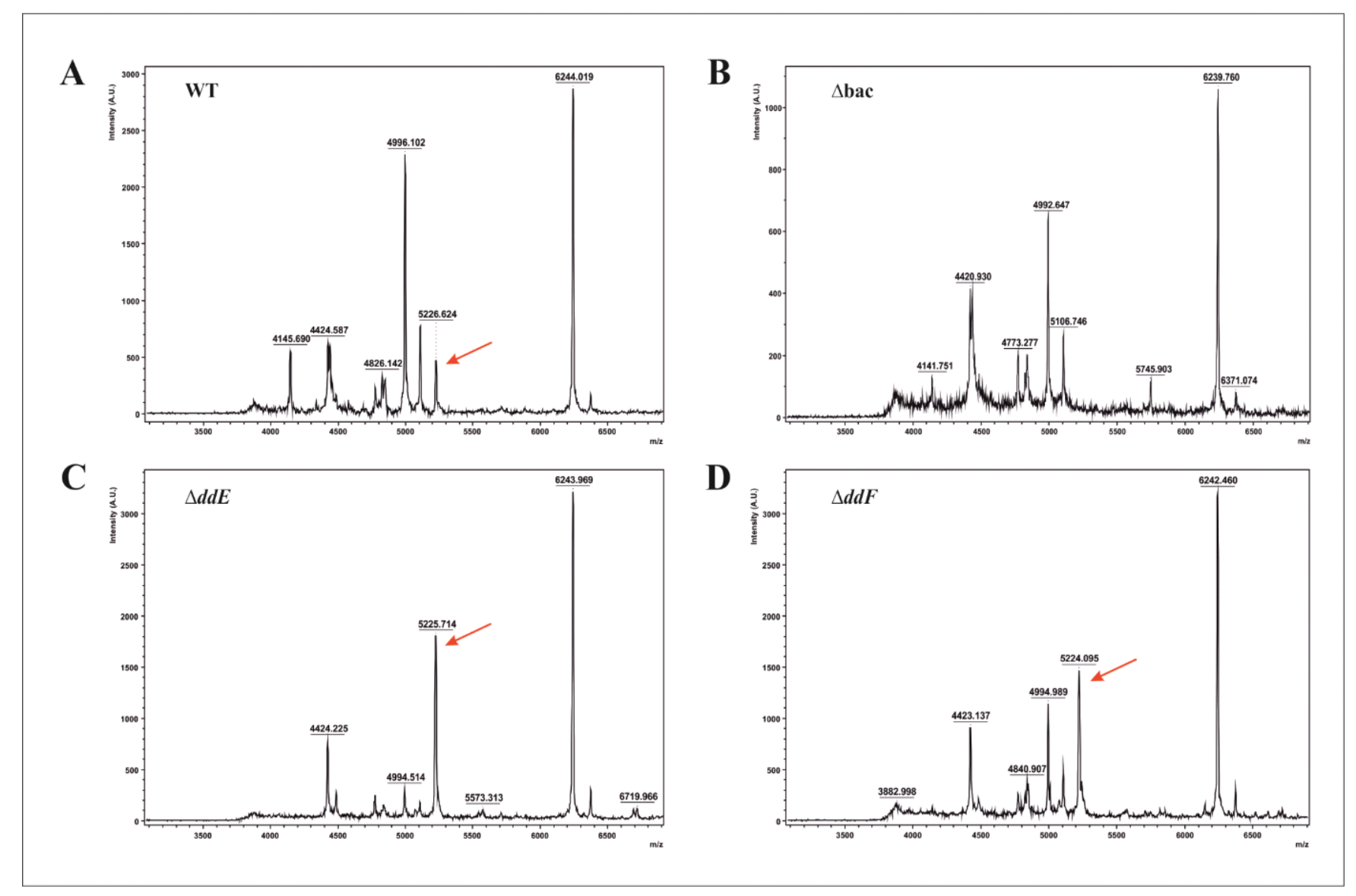

Figure 4. Matrix-assisted laser desorption ionization time-of-flight mass spectrometry (MALDI-TOF/MS) spectra obtained from intracellular fraction proteins of WT (A), $\Delta b a c(\mathbf{B}), \Delta d d E(\mathbf{C})$, and $\Delta d d F(\mathbf{D})$ strains. Red arrows mark the peaks corresponding to the EntDD14.

As expected, these data confirmed that EntDD14 is more accumulated in $\triangle d d E$ and $\Delta d d F$ mutant strains than the WT, arguing that these proteins have a key role in EntDD14 transport out of the cytoplasm.

\subsection{EntDD14 Accumulated inside the Cytoplasm Induces Cell Toxicity}

EntDD14 as above-stated accumulates inside the cell when DdE or DdF is missing. To verify the probable deleterious effect of this accumulation, we compared the kinetic growth of the mutants and complemented strains to that of the WT strain (Figure 5). These growth curves revealed discrepancies. The latency phase of the mutant strains is extended in the first hours of growth but reached the same $\mathrm{OD}_{600 \mathrm{~nm}}$ than that of the WT strain at the entrance of the stationary phase and remains constant throughout the $24 \mathrm{~h}$ of the experiment (Figure 5A). The growth rate $(\mu)$ of the mutant strain $\Delta d d E$ was $1.06 \pm 0.06$ and that of $\Delta d d F$ was $1.08 \pm 0.07$, and it does not differ from that of the WT strain, $1.16 \pm 0.05$. The complemented $\Delta d d F$-Comp strain shows the same behavior as the WT strain with a slightly lower growth rate, $1.01 \pm 0.06$, which can be ascribed to the presence of the 
pAT18: $d d F$ plasmid. Overall, the mutant strains have registered a loss in cell viability (Figure 5B). The CFU counts indicate that all strains had reached approximately the same number of viable cells at the end of the exponential phase, $\approx 3 \times 10^{9} \mathrm{CFU} \cdot \mathrm{mL}^{-1}$. However, after $24 \mathrm{~h}$ of growth, $\Delta d d E$ and $\Delta d d F$ mutant strains have registered 1 log reduction in CFU. $\mathrm{mL}^{-1}$ compared to the WT strain, which represents a $90 \%$ loss of cell viability. The loss of cell viability is not necessarily correlated to loss of turbidity of the bacterial culture, as cell lysis seems not to occur.

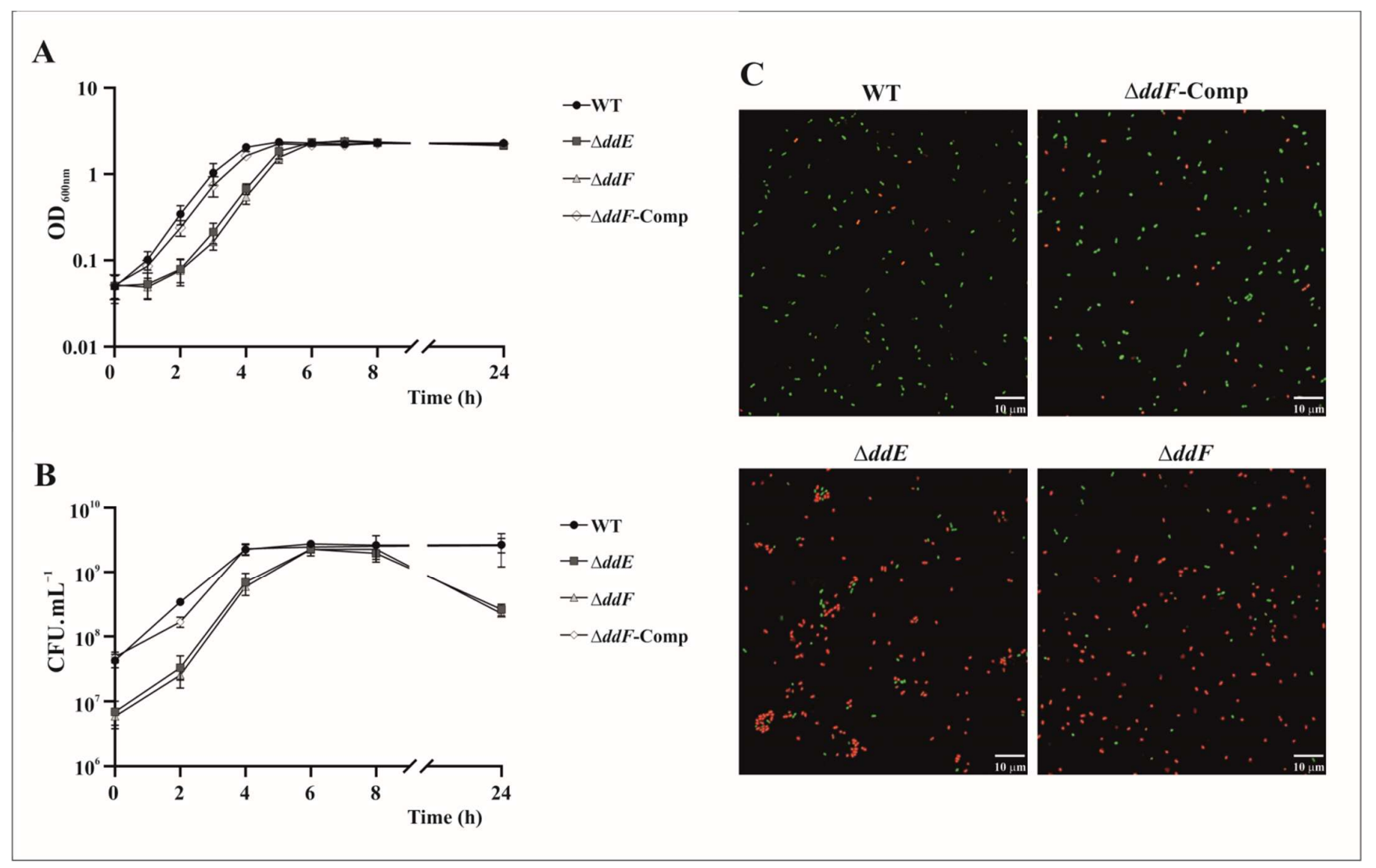

Figure 5. Analysis of bacterial growth of E. faecalis 14 strains by measuring the optical density at $600 \mathrm{~nm}$ (A) and by counting the colony-forming units per $\mathrm{mL}(\mathbf{B})$. (C) Confocal microscope images of bacteria stained with LIVE/DEAD viability kit at $24 \mathrm{~h}$ of bacterial growth.

To confirm this cell-viability feature in the $\Delta d d E$ and $\Delta d d F$ mutant strains, we performed a confocal microscopy analysis using the live/dead Bacterial Viability Kit. The $\triangle d d F$ and $\triangle d d E$ mutant strains showed similar numbers of bacterial cells but a very low live/dead ratio compared to the WT and the $\Delta d d F$-complemented strains (Figure 5C), revealing an abundance of bacteria with compromised membranes that were uncultivable. Therefore, the overall results support that in addition to provoking cell lysis, the intracellular accumulation of EntDD14 is deleterious in the mutant cells lacking $d d E$ or $d d F$ genes.

\section{Discussion}

The emergence of LLB has opened a new avenue in the field of bacteriocins mainly in understanding their biosynthetic pathway. These bacteriocins, which are composed of one to four peptides [14], do not undergo post-translational modifications or processing, and they are thought to be immediately active after their translation in the cytoplasm. EntDD14 is used here as a model of the two-peptide LLB because of its high sequence homology with its counterparts of the same group. 
Bacteriocin transport is most often mediated by Type IV-ABC transporters, which are known to expel toxic molecules out of the producing-cells $[5,8,10]$. Interestingly, this type of transporter is also involved in the transport of some LLB, such as aureocin A70 [39], aureocin A53 [16], EntD14 [21], lacticin Q, and lacticin Z [40,41]. Nevertheless, the EntDD14 and aureocin A53-producing bacteria altered at least in one protein of the ABC transporters machinery were able to expel only $25 \%$ of bacteriocin compared to the WT strain $[16,21]$, arguing the existence of alternative transport pathways.

Here, we propose, for the first time in the history of bacteriocins, a transport role for two PH domain proteins, viz DdE and DdF. These proteins would be dedicated to transport the two-peptide LLB EntDD14 out of the cell. This finding is based on a set of complementary data including in silico analyses, genetic experimental evidence, and RT-qPCR tools as well as mass spectrometry and microscopy. The mutant strains $\Delta d d E$ and $\triangle d d F$, lacking DdE and DdF, resulted in a loss of EntDD14 transport, albeit genes $(d d A B H I J)$ coding for EntDD14 and the ABC transporter were expressed. Consequently, the bacteriocin remained trapped inside the cell, leading finally to toxic internal activity. These data showed that LLB are indeed active inside the cytoplasm.

The deleterious effect of an LLB was also reported for the lacticin $Q$ when its coding gene was expressed in the absence of the $\ln q B C D E F$ genes [40]. Lacticin $Q$ is a singlepeptide LLB produced by Lactococcus lactis QU 5. The deletion of any of the $\ln q C D E F$ genes abolished the bacteriocin production. These authors suggested that $\ln q C D$ along with $\ln q B$ genes could play a role of accessory proteins to the ABC transporter formed by $\ln q E F$ genes [41]. It has been also reported that deletion of the orf8 gene in S. aureus A53 that produces another single-peptide LLB aureocin A53, enabled bacteriocin production [16]. The genetic determinants required for aureocin A53 synthesis are organized in at least four transcriptional units encoded by the 10.4-kb plasmid pRJ9. One of these units corresponds to the orf7 and orf8 genes. Interestingly, the sequence analyses of Orf7 and Orf8 from S. aureus A53 and LnqC and LnqD from L. lactis QU 5 showed homology to B. subtilis YdbS and YdbT proteins, respectively (Table 1), and also a certain level of homology with DdE and DdF proteins from $E$. faecalis 14.

The presence of proteins DdE and DdF with such domains were as well encountered in different operons related to two-peptide LLB L50 produced by different E. faecium strains. In all of them, these $\mathrm{PH}$ domain-containing proteins are highly conserved, reaching a homology score of $74 \%$ for DdE and $78 \%$ for DdF. These findings showed that this new transport pathway based on PH domain-containing proteins is not unique to EntDD14 but is common to several single- and two-peptide LLB.

The in silico analysis of DdE and DdF proteins enabled establishing the preliminary snapshot of their structures. Thus, DdE has structural similarities to proteins exerting electron transfer activity across the cell membrane. However, modeling of DdE did not explain how its $\mathrm{PH} b 2$ domain can interact in a transport function. On the other hand, the DdF protein has partial structural homology to ABC transporter proteins (Table 3), which are composed of two differentiated domains. The first is a dimeric cytoplasmic nucleotidebinding domain (NBD), and the second is a homo- or heterodimeric transmembrane domain (TMD). Of note, DdF was in turn predicted with six transmembrane $\alpha$-helices, which concurs with the consensus organization of TMD, which most often includes two sets of six hydrophobic helices [5,8]. The highest structural homology of DdF was obtained with the TMD and the C39 protease domain of the PCAT1 transporter from H. thermocellum [31]. This transporter belongs to the SunT-type ABC transporters, and it cleaves the leader peptide prior to its translocation across the membrane [5], where the C39 domain is responsible for the specific recognition of the peptide and its cleavage. The putative $\mathrm{PH} b 2$ domains in DdF seem to conform under a similar structure to that of the C39 domain, which could specifically recognize EntDD14 and facilitates its transport across the membrane.

The PH domain is widely encountered in Eukaryotic proteins where their sequences are not necessarily conserved. Nevertheless, all these proteins present the same folding in their structure, named the PH superfold, which is also shared with other domains such as 
the phosphotyrosine binding (PTB) domain, Enabled/VASP homology (EVH1) domain, and Ran-binding domain (RanBD). For this reason, the PH superfold was suggested as a scaffold for multiple functions [42]. The PH domain superfold includes proteins involved in binding to a variety of phosphoinositide and protein ligands, which mediate protein targeting to the membrane and protein interactions in signal transmission processes [43].

The PHb2 domain was described in exig_2160 protein from Exiguobacterium sibiricum 255-15. This protein is uncharacterized, and its function remains unknown, but its structural study showed the oligomerization of the protein involving twelve monomers binding by the PHb2 domain [24]. The PH $b 2$ domains in exig_2160 protein are composed by seven $\beta$ sheets and a C-terminal $\alpha$-helix. The prediction of DdE and DdF PHb2 domains' secondary structure showed also a predominance in $\beta$-sheet. Thus, we believe that the putative $\mathrm{PH} b 2$ domains in DdE and DdF proteins may be involved in their own interactions and/or in the recognition of EntDD14, leading to its transport across the membrane.

Here, we firmly believe that the DdE and DdF proteins, as well as their counterparts in the bacteriocin-producing bacteria, are not acting as accessory proteins as previously reported by Iwatini et al. [41] but constitute new carriers dedicated for LLB. Both DdE and DdF are simultaneously required for two-peptide LLB EntDD14 transport. Moreover, in all the YdbS/YdbT-like couple proteins reported in Table 1, the genes were not found associated with $\mathrm{ABC}$ transporter genes, which strengthens our data and thus allocates a transport function to DdE and DdF. Further analyses aimed to understand interactions between DdE and DdF as well as interactions between DdE and EntDD14 or DdF and EntDD14 constitute our next focus.

\section{Materials and Methods}

\subsection{Bacterial Strains and Growth Conditions}

Bacteria used in this work are listed in Table 4. Enterococcus faecalis strains were routinely grown in M17 medium supplemented with $0.5 \%$ glucose (GM17), at $37^{\circ} \mathrm{C}$. Escherichia coli strains were grown in Luria-Bertani (LB) broth at $37^{\circ} \mathrm{C}$ by shaking at $160 \mathrm{rpm}$. Listeria innocua ATCC33090 strain was grown in Brain-Heart Infusion (BHI) broth at $37^{\circ} \mathrm{C}$. When bacteria carried the pLT06 plasmid or its derivatives, the medium was supplemented with chloramphenicol $(\mathrm{Cm})$ at $10 \mu \mathrm{g} \cdot \mathrm{mL}^{-1}$ for $E$. coli and at $15 \mu \mathrm{g} \cdot \mathrm{mL}^{-1}$ for E. faecalis. When bacteria carried the pAT18 plasmid or its derivatives, the medium was supplemented with erythromycin (Em) at $150 \mu \mathrm{g} \cdot \mathrm{mL}^{-1}$ for E. coli and E. faecalis.

Table 4. List of the bacteria used in this work.

\begin{tabular}{|c|c|c|c|c|}
\hline Bacteria & Plasmids & Resistance & Characteristics & Reference \\
\hline \multicolumn{5}{|l|}{ Escherichia coli } \\
\hline XL1-Blue & - & - & $\begin{array}{l}\text { Plasmid-free type strain used for } \\
\text { plasmid cloning }\end{array}$ & Agilent Technologies \\
\hline XL1-Blue [plT06] & pLT06 & $\mathrm{Cm}^{\mathrm{R}}$ & $\begin{array}{l}\text { Source of the pLT06 plasmid used for } \\
\text { mutant strategies }\end{array}$ & [21] \\
\hline $\begin{array}{l}\text { XL1-Blue } \\
\text { [pLT06: } \Delta d d E]\end{array}$ & pLT06: $\Delta d d E$ & $\mathrm{Cm}^{\mathrm{R}}$ & $\begin{array}{l}\text { Derivative of pLT06 by cloning of a } \\
2219 \text { pb DNA fragment harboring } \\
\text { flanked regions of } d d E \text { gene }\end{array}$ & This study \\
\hline $\begin{array}{l}\text { XL1-Blue } \\
\text { [pLT06: } \Delta d d F]\end{array}$ & pLT06: $\Delta d d F$ & $\mathrm{Cm}^{\mathrm{R}}$ & $\begin{array}{l}\text { Derivative of pLT06 by cloning of a } \\
2019 \text { pb DNA fragment harboring } \\
\text { flanked regions of } d d F \text { gene }\end{array}$ & This study \\
\hline XL1-Blue[pAT18] & pAT18 & $\mathrm{Em}^{\mathrm{R}}$ & $\begin{array}{l}\text { Source of pAT18 used for } \\
\text { complementation studies, based on } \\
\text { the inducible lac promoter }\end{array}$ & [21] \\
\hline
\end{tabular}


Table 4. Cont

\begin{tabular}{|c|c|c|c|c|}
\hline Bacteria & Plasmids & Resistance & Characteristics & Reference \\
\hline $\begin{array}{l}\text { XL1-Blue } \\
\text { [pAT18:ddF] }\end{array}$ & pAT18:ddF & $\mathrm{Em}^{\mathrm{R}}$ & $\begin{array}{l}\text { Derivative of pAT18 by cloning of } d d F \\
\text { gene under the control of lac promoter }\end{array}$ & This study \\
\hline \multicolumn{5}{|c|}{ Enterococcus faecalis } \\
\hline 14 & - & - & $\begin{array}{l}\text { Natural strain isolated from } \\
\text { meconium }\end{array}$ & [17] \\
\hline $14 \Delta d d E$ & - & - & Deletion mutant strain of $d d E$ gene & This study \\
\hline $14 \Delta d d F$ & - & - & Deletion mutant strain of $d d F$ gene & This study \\
\hline $14 \Delta d d F-$ Comp & pAT18:ddF & $\operatorname{Em}^{\mathrm{R}}$ & $\begin{array}{l}\text { Derivative of pAT18 by cloning of } d d F \\
\text { gene under the control of lac promoter }\end{array}$ & This study \\
\hline \multicolumn{5}{|l|}{ Listeria innocua } \\
\hline ATCC33090 & - & - & & [21] \\
\hline
\end{tabular}

\subsection{Construction of the $\Delta d d E$ and $\Delta d d F$ Strains}

The ddE and ddF genes were separately deleted from the E. faecalis 14 chromosome by recombinant exchange with the surrounding regions of the genes, using a strategy based on the conditional replication of the pLT06 plasmid [37]. The oligonucleotides used for this purpose are listed in Table 5. The flanking regions of each gene were amplified by PCR using the genomic DNA of E. faecalis 14 as the template, the corresponding $1 \mathrm{~F} / 2 \mathrm{R}$ (upstream) and 3F/4R (downstream) oligonucleotide pairs, and the Phusion ${ }^{\mathrm{TM}}$ High-Fidelity DNA Polymerase Mix (ThermoFisher Scientific, Waltham, MA, USA). The $2 \mathrm{R}$ and $3 \mathrm{~F}$ oligonucleotides have a region of 24 complementary nucleotides, which allowed us to amplify both fragments together, using a mixture of the two fragments as a template and the $1 \mathrm{~F} / 4 \mathrm{R}$ oligonucleotide pairs. This complementary region is the one that replaces the deleted gene in the mutant strain. Thus, four stop codons were inserted to avoid any undesired translation. Final amplicons were purified from $1 \%$ agarose gel. They as well as the pLT06 plasmid were digested with PstI and NcoI restriction enzymes (ThermoFisher Scientific, USA) and finally ligated overnight with T4 ligase (ThermoFisher Scientific, USA). The ligation mixtures were used to transform E. coli XL1-Blue by heat shock. Transformed colonies were selected on LB agar plates supplemented with $\mathrm{Cm}$ at $10 \mu \mathrm{g} \cdot \mathrm{mL}-1$ and X-gal at $80 \mu \mathrm{g} \cdot \mathrm{mL}-1$. A blue positive colony of each construction was cultured to extract the pLT06: $\triangle \mathrm{ddE}$ and pLT06: $\triangle \mathrm{ddF}$ plasmids. These plasmids were confirmed by PCR and sequencing. A quantity of $0.5 \mu \mathrm{g}$ of both plasmids was used to transform $50 \mu \mathrm{L}$ of electrocompetent cells of E. faecalis 14 by electroporation $(25 \mu \mathrm{F}, 2.5 \mathrm{kV}$, and $200 \Omega$ in pre-chilled $0.2 \mathrm{~cm}$ cuvettes). Transformed colonies were selected on M17-agar plates supplemented with $\mathrm{Cm}$ at $15 \mu \mathrm{g} \cdot \mathrm{mL}-1$ and X-gal at $80 \mu \mathrm{g} \cdot \mathrm{mL}-1$ at $30{ }^{\circ} \mathrm{C}$.

Table 5. List of oligonucleotides used in this work.

\begin{tabular}{|c|c|c|c|}
\hline Oligonucleotide & Sequence $3^{\prime}-5^{\prime}$ & Utilization & $\begin{array}{l}\text { Amplicon Size } \\
(\mathrm{pb})\end{array}$ \\
\hline ddE 1F-PstI & $\begin{array}{l}\text { ATTAAACTGCAGTGATATACAATT- } \\
\text { TATATGAACAA }\end{array}$ & \multirow{2}{*}{$\begin{array}{l}\text { Amplification of } d d E \text { upstream } \\
\text { fragment }\end{array}$} & \multirow{2}{*}{1136} \\
\hline ddE 2R-Stop & $\begin{array}{l}\text { CATTCACTAGGATCCTTAGACTT- } \\
\text { ATACAAATTCATTTTTCATTGAA }\end{array}$ & & \\
\hline ddE 3F-Stop & $\begin{array}{l}\text { TAAGTCTAAGGATCCTAGTGAAT- } \\
\text { GAAGAAGAGGTTATTAGATGAA }\end{array}$ & \multirow{2}{*}{$\begin{array}{l}\text { Amplification of } d d E \text { downstream } \\
\text { fragment }\end{array}$} & \multirow{2}{*}{1107} \\
\hline ddE 4R-NcoI & $\begin{array}{l}\text { ATTAAACCATGGTATCTATAGCCAT- } \\
\text { AAAAATAGCC }\end{array}$ & & \\
\hline
\end{tabular}


Table 5. Cont.

\begin{tabular}{|c|c|c|c|}
\hline Oligonucleotide & Sequence $3^{\prime}-5^{\prime}$ & Utilization & $\begin{array}{l}\text { Amplicon Size } \\
(\mathrm{pb})\end{array}$ \\
\hline ddE 5F & AGATATATTGATATACAATTTATATG & \multirow{2}{*}{$\begin{array}{l}\text { Outer primer; verification of the } \\
\text { plasmid integration }\end{array}$} & \multirow{2}{*}{-} \\
\hline ddE 6R & ACTATCAAAАTATCTCTTACATAC & & \\
\hline ddF 1F-PstI & $\begin{array}{l}\text { ATTAAACTGCAGGTCTATTATAGG- } \\
\text { AGGTAAAAATG }\end{array}$ & \multirow{2}{*}{$\begin{array}{l}\text { Amplification of } d d F \text { upstream } \\
\text { fragment }\end{array}$} & \multirow{2}{*}{1016} \\
\hline ddF 2R-Stop & $\begin{array}{l}\text { CATTCACTAGGATCCTTAGACTTA- } \\
\text { TTTCATCTAATAACCTCTTCTTTTA }\end{array}$ & & \\
\hline ddF 3F-Stop & $\begin{array}{l}\text { TAAGTCTAAGGATCCTAGTGAATG- } \\
\text { TCGTAGGAGGATAGAATGAAC }\end{array}$ & \multirow{2}{*}{$\begin{array}{l}\text { Amplification of } d d F \text { downstream } \\
\text { fragment }\end{array}$} & \multirow{2}{*}{1027} \\
\hline ddF 4R-NcoI & $\begin{array}{l}\text { ATTAAACCATGGGGCTTTTTTCATT- } \\
\text { TCATCATCC }\end{array}$ & & \\
\hline $\mathrm{ddF} 5 \mathrm{~F}$ & AAACGAAAGGGGACTGTAGC & \multirow{2}{*}{$\begin{array}{l}\text { Outer primer; verification of the } \\
\text { plasmid integration }\end{array}$} & \multirow{2}{*}{-} \\
\hline ddF 6R & TCAATTTTATTATCAGCTTCAGC & & \\
\hline ddF CompF-KpnI & $\begin{array}{l}\text { AAAAGGTACCAATAAAAGA- } \\
\text { AGAGGTTATTAGATG }\end{array}$ & \multirow{2}{*}{ Cloning of the $d d F$ gene in pAT18 } & \multirow{2}{*}{1434} \\
\hline ddF CompR-BamHI & $\begin{array}{l}\text { AAAAGGATCCTGTTCATTC- } \\
\text { TATCCTCCTACG }\end{array}$ & & \\
\hline oriF & CAATAATCGCATCCGATTGCA & \multirow{2}{*}{$\begin{array}{l}\text { Cloning verification in pLT06 } \\
\text { plasmid }\end{array}$} & \multirow[t]{2}{*}{-} \\
\hline Ks05R & CCTATTATACCATATTTTGGAC & & \\
\hline PU & GTAAAACGACGGCCAGT & \multirow{2}{*}{$\begin{array}{l}\text { Cloning verification in pAT18 } \\
\text { plasmid }\end{array}$} & \multirow{2}{*}{-} \\
\hline PR & CAGGAAACAGCTATGAC & & \\
\hline EntAL & ATGGGAGCAATCGCAAAAT & \multirow{2}{*}{$\begin{array}{l}\text { Amplification of internal } d d A \text { gene } \\
\text { fragment for qPCR }\end{array}$} & \multirow{2}{*}{100} \\
\hline EntAR & TAATTGCCCATCCTTCTCCA & & \\
\hline EntBL & AAAGTTTGGATGGCCATTTATT & \multirow{2}{*}{$\begin{array}{l}\text { Amplification of internal } d d B \text { gene } \\
\text { fragment for qPCR }\end{array}$} & \multirow{2}{*}{106} \\
\hline EntBR & TCAATGTCTTTTTAACCATTTTTCA & & \\
\hline EL & ACAAGAACATATACATTTGTGAAGGA & \multirow{2}{*}{$\begin{array}{l}\text { Amplification of internal } d d E \text { gene } \\
\text { fragment for qPCR }\end{array}$} & \multirow{2}{*}{95} \\
\hline ER & AACATATTCTGTTTCAATTACCGTGT & & \\
\hline FL & AGGAAAATGTTGATTTGGTGTTT & \multirow{2}{*}{$\begin{array}{l}\text { Amplification of internal } d d F \text { gene } \\
\text { fragment for } \mathrm{qPCR}\end{array}$} & \multirow{2}{*}{100} \\
\hline FR & TCCAATGAAGATAACAAGACAAAAA & & \\
\hline HL & TGGTCAAGAAATCAATGAAAATG & \multirow{2}{*}{$\begin{array}{l}\text { Amplification of internal } d d H \text { gene } \\
\text { fragment for qPCR }\end{array}$} & \multirow{2}{*}{89} \\
\hline HR & CTAGAGATTGGGTTTGTTCTTCC & & \\
\hline IL & GGGATTTATCGATCGTAAGTTTG & \multirow{2}{*}{$\begin{array}{l}\text { Amplification of internal } d d I \text { gene } \\
\text { fragment for } \mathrm{qPCR}\end{array}$} & \multirow{2}{*}{86} \\
\hline IR & TTTTAGAAAGAATGTCATCTGCTGT & & \\
\hline JL & AGAAGGAGTTAAACCCGATAAGG & \multirow{2}{*}{$\begin{array}{l}\text { Amplification of internal } d d J \text { gene } \\
\text { fragment for qPCR }\end{array}$} & \multirow{2}{*}{87} \\
\hline JR & TCATATTCTCCCAGATGTCTCAA & & \\
\hline
\end{tabular}

The first recombinant event was induced as follows. Transformant strains harboring pLT06: $\triangle d d E$ or pLT06: $\Delta d d F$ were grown in GM17 broth supplemented with Cm at $15 \mu \mathrm{g} \cdot \mathrm{mL}$ 1 at $30^{\circ} \mathrm{C}$ for $2 \mathrm{~h}$; then, they were shifted to $42{ }^{\circ} \mathrm{C}$ for $4 \mathrm{~h}$. At this temperature, the replicon of the pLT06 plasmid was disabled, and with the selection pressure of the $\mathrm{Cm}$, its integration into the chromosome by recombination was forced. Larger blue colonies grown on M17agar plates $(\mathrm{Cm}+\mathrm{X}$-gal) were verified by PCR using the outer $5 \mathrm{~F}$ oligonucleotides with one of the oligonucleotides located on the plasmid (OriF or KS05seqR, in Table 5). One of these colonies from each mutant was subjected to the second recombinant event. The colonies were grown in GM17 broth in the absence of $\mathrm{Cm}$ at $30^{\circ} \mathrm{C}$. The cultures were 
diluted several times growing until stationary phase. At $30{ }^{\circ} \mathrm{C}$, the replicon of pLT06 is functional, provoking the excision from the chromosome, and without the antibiotic pressure, the loss of the plasmid was favored. White colonies grown in M17-agar-X-gal plates without $\mathrm{Cm}$ were screened for the mutant genotype by PCR using the outer 5F/6R oligonucleotide pairs. The suitable mutants for $d d E$ and $d d F$ gene deletions were verified by sequencing the surrounding genetic environment.

\subsection{Complementation of the E. faecalis $\Delta d d F$ Mutant Strain}

To complement the $\triangle d d F$ mutant strain, the gene $d d F$ was cloned into the pAT18 plasmid [38]. The DNA fragment containing the $d d F$ gene was amplified by PCR using the ddF Comp oligonucleotides (Table 5). The amplicon and the pAT18 plasmid were digested with $\mathrm{KpnI}$ and BamHI restriction enzymes and ligated overnight with the T4 ligase. The ligation mixture was used to transform E. coli XL1-Blue by heat shock. Transformed colonies were selected on LB agar plates supplemented with Em at $150 \mu \mathrm{g} \cdot \mathrm{mL}^{-1}$ and X-gal at $80 \mu \mathrm{g} \cdot \mathrm{mL}^{-1}$. A white positive colony of each construction was cultured to extract the pAT18:ddF plasmid. This plasmid was confirmed by PCR and sequencing. Then, $0.5 \mu \mathrm{g}$ of the plasmid was used to transform $50 \mu \mathrm{L}$ of electro-competent cells of $E$. faecalis $14 \Delta d d F$ strain by electroporation ( $25 \mu \mathrm{F}, 2.5 \mathrm{kV}$, and $200 \Omega$ in pre-chilled $0.2 \mathrm{~cm}$ cuvettes). Transformed colonies were selected on M17 agar plates supplemented with Em at $150 \mu \mathrm{g} \cdot \mathrm{mL}^{-1}$ and X-gal at $80 \mu \mathrm{g} \cdot \mathrm{mL}^{-1}$.

To test the antibacterial activity of the complemented strain, the Em of the medium must be removed. Nonetheless, we performed a plasmid stability study to analyze the presence of the plasmid over time. Thus, the complemented strain was cultured during 10 and 30 generations in GM17 without Em. At these points, the percentage of cells harboring the plasmid was calculated by counting the UFC. $\mathrm{mL}^{-1}$ on M17 agar plates containing or not Em at $150 \mu \mathrm{g} \cdot \mathrm{mL}^{-1}$.

\subsection{Antimicrobial Activity against L. innocua}

The screening of anti-L. innocua activity of the cell-free supernatant from E. faecalis $14 \mathrm{WT}$ and mutant strains, as well as purified EntDD14 was performed using the wellknown agar diffusion method [18]. Briefly, a uniform layer of Listeria culture was deposited on a soft BHI-agar (1\%) plate using a swab. Then, wells of $5 \mathrm{~mm}$ diameter were aseptically made in the agar. After that, $50 \mu \mathrm{L}$ of cell-free supernatants and/or purified EntDD14 were introduced, separately, into the wells. Then, the plates were incubated at $4{ }^{\circ} \mathrm{C}$ for $1 \mathrm{~h}$ and then overnight at $37^{\circ} \mathrm{C}$. The absence or presence of inhibitory zones around the wells was recorded.

\section{5. $R N A$ Isolation and $R T-q P C R$}

Quantitative reverse transcription PCR (RT-qPCR) analysis was carried out to study the expression of genes involved in enterocin DD14 production and transport in E. faecalis $14 \mathrm{WT}$ and $\triangle d d E$ and $\Delta d d F$ strains. At $5 \mathrm{~h}$ and $24 \mathrm{~h}$, cultures of these strains were performed. Cells were harvested by centrifugation $\left(10,000 \times g\right.$ during $10 \mathrm{~min}$ at $\left.4{ }^{\circ} \mathrm{C}\right)$, and total RNA was extracted using the NucleoSpin ${ }^{\mathrm{TM}}$ RNA Plus columns (Macherey-Nagel, Hoerdt, France). The quantity and quality of RNA samples were determined by capillary electrophoresis, using an Agilent 2100 Bioanalyzer (Agilent Technologies, Les Ulis, France), and a minimal RNA integrity number (RIN) of 8 was required for all samples. First, $1 \mu \mathrm{g}$ of total RNA from each sample was treated with DNase (Thermo Fisher Scientific) to remove all traces of DNA. After DNase inactivation with EDTA (Thermo Fisher Scientific), the RNA was converted to complementary DNA (cDNA) using the RevertAid H Minus First Strand cDNA Synthesis Kit (Thermo Fisher Scientific). Changes in the mRNA expression of several genes ( $d d A, d d B, d d E, d d F, d d H, d d I$, and $d d J)$ were monitored by real-time qPCR, performed with the Brilliant III SYBR Green QPCR Master Mix (Agilent Technologies) on a "CFX Connect Real-Time PCR Detection System" thermocycler (BIO-RAD). The oligonucleotides used are listed in Table 5. The mean CT of each sample was normalized against the house- 
keeping gene (gyrase) and the corresponding control. The relative quantification of each gene was calculated by the $2^{-(\Delta \Delta \mathrm{Ct})}$ method, using the Bio-Rad's CFX Manager software.

\subsection{Intracellular Protein Extraction}

Overnight cultures of E. faecalis 14 strains (WT, $\Delta b a c, \Delta d d E, \Delta d d F$, and $\Delta d d F$-Comp) were diluted in fresh GM17 medium and grown at $37{ }^{\circ} \mathrm{C}$ for $24 \mathrm{~h}$. Then, the cells were harvested by centrifugation $\left(10,000 \times g\right.$ during $10 \mathrm{~min}$ at $\left.4{ }^{\circ} \mathrm{C}\right)$ and resuspended in lysis buffer $(20 \mathrm{mM}$ Tris- $\mathrm{HCl} \mathrm{pH} 8.0,300 \mathrm{mM} \mathrm{NaCl})$ and then sonicated in an ice bath using the OmniRuptor 4000 Ultrasonic Homogenizer (OMNI International, Kennesaw, GA, USA). Their concentrations were determined by the bicinchoninic acid (BCA) assay protein kit (Sigma-Aldrich, St Louis, MI, USA), following the manufacturer's recommendations.

\subsection{Purification of the Leaderless Two-Peptides EntDD14}

EntDD14 was purified from the supernatant of E. faecalis $14 \mathrm{WT}, \Delta d d E, \Delta d d F$, and $\triangle d d F$-Comp strains. The purification procedure was adapted from Abriouel et al. [44] as follows. Each strain was grown in $200 \mathrm{~mL}$ of GM17 at $37^{\circ} \mathrm{C}$ for $24 \mathrm{~h}$. After harvesting of the cultures by centrifugation $\left(10,000 \times g\right.$ during $10 \mathrm{~min}$ at $\left.4{ }^{\circ} \mathrm{C}\right)$, the obtained cell-free supernatants were incubated at room temperature for $24 \mathrm{~h}$ with the CM Sephadex ${ }^{\circledR} \mathrm{C}$ 25 resin (GE Healthcare Life Sciences, Issaquah, WA) with shaking at $90 \mathrm{rpm}$. The mixture was poured into a chromatography column, where the resin was allowed to settle. Then, the resin was washed with $400 \mathrm{~mL}$ of distilled water and $200 \mathrm{~mL}$ of $0.5 \mathrm{M} \mathrm{NaCl}$. Then, the resin-bound DD14 was eluted with $30 \mathrm{~mL}$ of $1.5 \mathrm{M} \mathrm{NaCl}$. The solution containing DD14 was desalted by gel filtration using PD MidiTrap G-10 columns (GE), eluting with milliQ water. The pure EntDD14 was quantified using the BCA assay protein kit (Sigma-Aldrich) and then, it was dried in aliquots by miVac Sample Concentrators (SP Scientific, Gardiner, NY, USA) for its storage. When used, an aliquot of pure DD14 was resuspended in the appropriate volume of MilliQ water to achieve the desired concentration.

\subsection{Detection of EntDD14 by MALDI-TOF/MS}

EntDD14 in cell-free supernatants as well as in intracellular protein fractions of WT and mutant strains were detected by matrix-assisted laser desorption ionization timeof-flight mass spectrometry (MALDI-TOF/MS). The analysis was carried out using the Autoflex Speed MALDI TOF/TOF equipment (Bruker Daltonics, Bremen, Germany), and spectra were obtained using flexAnalysis software (Bruker Daltonics, Germany). When required, the samples were concentrated using Pierce ${ }^{\mathrm{TM}} \mathrm{C} 18$ tips (Thermo Scientific).

\subsection{Evaluation of the Effect on the Producer Strains by Ent DD14 Intracellular Accumulation}

To evaluate the effect of accumulated EntDD14 inside the cells in mutant strains, we examined the bacterial growth of WT, $\Delta d d E, \Delta d d F$, and $\Delta d d F-C o m p$ strains. Overnight cultures were diluted in fresh GM17 medium to $\mathrm{OD}_{600 \mathrm{~nm}}=0.05$, and the bacterial growth was followed by hourly measuring the $\mathrm{OD}_{600 \mathrm{~nm}}$ with a spectrophotometer (Aqualabo, Champigny sur Marne, France) during $24 \mathrm{~h}$. The UFC $\cdot \mathrm{mL}^{-1}$ were obtained by counting on M17 agar plates at $0,2,4,6,8$, and 24 h of growth.

\subsection{Confocal Laser Scanning Microscopy}

Cultures of WT, $\Delta$ bac, $\Delta d d E, \Delta d d F$, and $\Delta d d F$-Comp strains were treated with the LIVE/DEAD ${ }^{\mathrm{TM}}$ BacLight $^{\mathrm{TM}}$ Bacterial Viability Kit (Thermo Fisher Scientific, Landsmeer Netherlands) to analyze the viability of the bacteria at $24 \mathrm{~h}$ of growth. The staining procedure was carried out following the manufacturer's instructions. Stained bacterial solutions were imaged with a ZEISS LSM 780 confocal laser scanning microscope equipped with a 40x/1.3 oil immersion objective (Carl Zeiss Micro Imaging GmbH, München, Germany). The SYTO 9 dye was excited with a laser at $488 \mathrm{~nm}$ and detected between 493 and $560 \mathrm{~nm}$; and the propidium iodide dye was excited at $561 \mathrm{~nm}$ and detected between 584 and $718 \mathrm{~nm}$. The images were acquired with the Zen software (Carl Zeiss Micro Imaging GmbH, Ger- 
many), and analyzed with the ImageJ software (National Institute of Health, Bethesda, MD, USA).

\subsection{Bioinformatics}

The E. faecalis 14 genome sequence was obtained from GenBank under the accession number CP021161.1. The sequences were analyzed using the Basic Local Alignment Search Tool of the National Center for Biotechnology Information (BLAST-NCBI: https:/ / blast. ncbi.nlm.nih.gov / Blast.cgi, accessed on 2 April 2020) and the SnapGene ${ }^{\circledR} 4.3 .7$ tool. The prediction of transmembrane helices in proteins was carried out with the TMHMM server v. 2.0 (http:/ / www.cbs.dtu.dk/services/TMHMM-2.0/ accessed on 14 June 2020) [45]. The structural model predictions were obtained using the online server Iterative Threading ASSEmbly Refinement (I-Tasser: https: / / zhanglab.ccmb.med.umich.edu/I-TASSER/ accessed on 4 May 2020) [25,26].

\subsection{Statistical Analysis}

All the results presented in this work were obtained from three independent experiments, and the data are expressed as the mean standard deviation. RT-qPCR results were statistically analyzed by one-way analysis of variance (ANOVA), followed by the Tukey's test to determine the significant differences between the variables at $p$ values $<0.05$.

Author Contributions: Conceptualization, A.P.-R., R.L., A.B. and D.D.; Data curation, A.P.-R.; Formal analysis, A.P.-R., R.L., A.B. and D.D.; Funding acquisition, D.D.; Methodology, A.P.-R.; Supervision, D.D.; Validation, A.P.-R., R.L., A.B. and D.D.; Writing-original draft, A.P.-R.; Writing-review and editing, A.P.-R., R.L., A.B. and D.D. All authors have read and agreed to the published version of the manuscript.

Funding: This work has been supported by the CPER/FEDER grant awarded by la Région des Hauts-de-France (2016-2021).

Institutional Review Board Statement: Not applicable.

Informed Consent Statement: Not applicable.

Data Availability Statement: Not applicable.

Acknowledgments: The MALDI-TOF/MS profiling experiments to detect the EntDD14 were performed on the REALCAT platform (Lille University), funded by the French National Research Agency (ANR) program [ANR-11-EQPX-0037]. The authors would like to thank Paloma Lopez and Stephen W. Elson for their critical reading of the manuscript.

Conflicts of Interest: The authors declare no competing interest.

\section{References}

1. Drider, D.; Rebuffat, S. Prokariotic Antimicrobial Peptides: From Genes to Applications; Springer: Berlin/Heidelberg, Germany, 2011.

2. Hammami, R.; Fernandez, B.; Lacroix, C.; Fliss, I. Anti-infective properties of bacteriocins: An update. Cell. Mol. Life Sci. 2013, 70, 2947-2967. [CrossRef]

3. Flaherty, R.A.; Freed, S.D.; Lee, S.W. The wide world of ribosomally encoded bacterial peptides. PLoS Pathog. 2014,10, e1004221. [CrossRef]

4. Alvarez-Sieiro, P.; Montalbán-López, M.; Mu, D.; Kuipers, O.P. Bacteriocins of lactic acid bacteria: Extending the family. Appl. Microbiol. Biotechnol. 2016, 100, 2939-2951. [CrossRef]

5. Beis, K.; Rebuffat, S. Multifaceted abc transporters associated to microcin and bacteriocin export. Res. Microbiol. 2019, 170, 399-406. [CrossRef]

6. Soltani, S.; Hammami, R.; Cotter, P.D.; Rebuffat, S.; Said, L.B.; Gaudreau, H.; Bedard, F.; Biron, E.; Drider, D.; Fliss, I. Bacteriocins as a new generation of antimicrobials: Toxicity aspects and regulations. FEMS Microbiol. Rev. 2021, 45, fuaa039. [CrossRef]

7. Ortega, M.A.; van der Donk, W.A. New insights into the biosynthetic logic of ribosomally synthesized and post-translationally modified peptide natural products. Cell Chem. Biol. 2016, 23, 31-44. [CrossRef]

8. Zheng, S.; Sonomoto, K. Diversified transporters and pathways for bacteriocin secretion in gram-positive bacteria. Appl. Microbiol. Biotechnol. 2018, 102, 4243-4253. [CrossRef] 
9. Cintas, L.M.; Casaus, P.; Håvarstein, L.S.; Hernández, P.E.; Nes, I.F. Biochemical and genetic characterization of enterocin p, a novel sec-dependent bacteriocin from Enterococcus faecium $\mathrm{p} 13$ with a broad antimicrobial spectrum. Appl. Environ. Microbiol. 1997, 63, 4321-4330. [CrossRef] [PubMed]

10. Smits, S.H.J.; Schmitt, L.; Beis, K. Self-immunity to antibacterial peptides by abc transporters. FEBS Lett. 2020, 594, 3920-3942. [CrossRef] [PubMed]

11. Ra, R.; Beerthuyzen, M.M.; de Vos, W.M.; Saris, P.E.J.; Kuipers, O.P. Effects of gene disruptions in the nisin gene cluster of Lactococcus lactis on nisin production and producer immunity. Microbiology 1999, 145, 1227-1233. [CrossRef] [PubMed]

12. Diaz, M.; Valdivia, E.; Martínez-Bueno, M.; Fernández, M.; Soler-González, A.S.; Ramírez-Rodrigo, H.; Maqueda, M. Characterization of a new operon, as-48efgh, from the as-48 gene cluster involved in immunity to enterocin as-48. Appl. Environ. Microbiol. 2003, 69, 1229-1236. [CrossRef]

13. Cintas, L.M.; Casaus, P.; Holo, H.; Hernandez, P.E.; Nes, I.F.; Håvarstein, L.S. Enterocins 150a and 150b, two novel bacteriocins from Enterococcus faecium 150, are related to staphylococcal hemolysins. J. Bacteriol. 1998, 180, 1988-1994. [CrossRef]

14. Perez, R.H.; Zendo, T.; Sonomoto, K. Circular and leaderless bacteriocins: Biosynthesis, mode of action, applications, and prospects. Front. Microbiol. 2018, 9, 2085. [CrossRef] [PubMed]

15. Netz, D.J.; Sahl, H.G.; Marcelino, R.; dos Santos Nascimento, J.; de Oliveira, S.S.; Soares, M.B.; do Carmo de Freire Bastos, M. Molecular characterisation of aureocin a70, a multi-peptide bacteriocin isolated from Staphylococcus aureus. J. Mol. Biol. 2001, 311, 939-949. [CrossRef] [PubMed]

16. Nascimento, J.d.S.; Coelho, M.L.V.; Ceotto, H.; Potter, A.; Fleming, L.R.; Salehian, Z.; Nes, I.F.; Bastos, M.d.C.d.F. Genes involved in immunity to and secretion of aureocin a53, an atypical class ii bacteriocin produced by Staphylococcus aureus a53. J. Bacteriol. 2012, 194, 875-883. [CrossRef]

17. Al Atya, A.K.; Drider-Hadiouche, K.; Ravallec, R.; Silvain, A.; Vachee, A.; Drider, D. Probiotic potential of Enterococcus faecalis strains isolated from meconium. Front. Microbiol. 2015, 6, 227. [CrossRef]

18. Caly, D.L.; Chevalier, M.; Flahaut, C.; Cudennec, B.; Al Atya, A.K.; Chataigne, G.; D'Inca, R.; Auclair, E.; Drider, D. The safe enterocin dd14 is a leaderless two-peptide bacteriocin with anti-Clostridium perfringens activity. Int. J. Antimicrob. Agents 2017, 49, 282-289. [CrossRef]

19. Antonio, M.M.-P.; Eva, V.; Magdalena, R.-R.; Juan, J.S.; Manuel, M.-V.; Mercedes, M.; Manuel, M.-B. Characterization of antimicrobial substances produced by Enterococcus faecalis mrr 10-3, isolated from the uropygial gland of the hoopoe (upupa epops). Appl. Environ. Microbiol. 2006, 72, 4245-4249.

20. Liu, X.; Vederas, J.C.; Whittal, R.M.; Zheng, J.; Stiles, M.E.; Carlson, D.; Franz, C.M.A.P.; McMullen, L.M.; van Belkum, M.J. Identification of an n-terminal formylated, two-peptide bacteriocin from Enterococcus faecalis 710c. J. Agric. Food Chem. 2011, 59, 5602-5608. [CrossRef]

21. Ladjouzi, R.; Lucau-Danila, A.; Benachour, A.; Drider, D. A leaderless two-peptide bacteriocin, enterocin dd14, is involved in its own self-immunity: Evidence and insights. Front. Bioeng. Biotechnol. 2020, 8, 644. [CrossRef]

22. Rebecchi, M.J.; Scarlata, S. Pleckstrin homology domains: A common fold with diverse functions. Annu. Rev. Biophys. Biomol. Struct. 1998, 27, 503-528. [CrossRef]

23. Lemmon, M.A.; Keleti, D. Ph domains. In Modular Protein Domains; Cesareni, G., Gimona, M., Sudol, M., Yaffe, M., Eds.; Wiley-VCH Verlag: Hoboken, NJ, USA, 2004; pp. 337-363.

24. Xu, Q.; Bateman, A.; Finn, R.D.; Abdubek, P.; Astakhova, T.; Axelrod, H.L.; Bakolitsa, C.; Carlton, D.; Chen, C.; Chiu, H.J.; et al. Bacterial pleckstrin homology domains: A prokaryotic origin for the ph domain. J. Mol. Biol. 2010, 396, 31-46. [CrossRef]

25. Yang, J.; Zhang, Y. I-tasser server: New development for protein structure and function predictions. Nucleic Acids Res. 2015, 43, W174-W181. [CrossRef]

26. Wang, Y.; Virtanen, J.; Xue, Z.; Zhang, Y. I-tasser-mr: Automated molecular replacement for distant-homology proteins using iterative fragment assembly and progressive sequence truncation. Nucleic Acids Res. 2017, 45, W429-W434. [CrossRef] [PubMed]

27. Sousa, J.S.; Calisto, F.; Langer, J.D.; Mills, D.J.; Refojo, P.N.; Teixeira, M.; Kühlbrandt, W.; Vonck, J.; Pereira, M.M. Structural basis for energy transduction by respiratory alternative complex iii. Nat. Commun. 2018, 9, 1728. [CrossRef]

28. Sun, C.; Benlekbir, S.; Venkatakrishnan, P.; Wang, Y.; Hong, S.; Hosler, J.; Tajkhorshid, E.; Rubinstein, J.L.; Gennis, R.B. Structure of the alternative complex iii in a supercomplex with cytochrome oxidase. Nature 2018, 557, 123-126. [CrossRef] [PubMed]

29. Sureshan, V.; Deshpande, C.N.; Boucher, Y.; Koenig, J.E.; Midwest Center for Structural Genomics; Stokes, H.W.; Harrop, S.J.; Curmi, P.M.G.; Mabbutt, B.C. Integron gene cassettes: A repository of novel protein folds with distinct interaction sites. PLoS ONE 2013, 8, e52934. [CrossRef]

30. Lee, C.-H.; MacKinnon, R. Structures of the human hon1 hyperpolarization-activated channel. Cell 2017, 168, 111-120. [CrossRef] [PubMed]

31. Lin, D.Y.; Huang, S.; Chen, J. Crystal structures of a polypeptide processing and secretion transporter. Nature 2015, 523, 425-430. [CrossRef]

32. Hohl, M.; Briand, C.; Grütter, M.G.; Seeger, M.A. Crystal structure of a heterodimeric ABC transporter in its inward-facing conformation. Nat. Struct. Mol. Biol. 2012, 19, 395-402. [CrossRef] [PubMed]

33. Lee, J.Y.; Yang, J.G.; Zhitnitsky, D.; Lewinson, O.; Rees, D.C. Structural basis for heavy metal detoxification by an atm1-type abc exporter. Science 2014, 343, 1133-1136. [CrossRef] 
34. Kumaran, D.; Eswaramoorthy, S.; Furey, W.; Navaza, J.; Sax, M.; Swaminathan, S. Domain organization in clostridium botulinum neurotoxin type e is unique: Its implication in faster translocation. J. Mol. Biol. 2009, 386, 233-245. [CrossRef]

35. Rempel, S.; Gati, C.; Nijland, M.; Thangaratnarajah, C.; Karyolaimos, A.; de Gier, J.W.; Guskov, A.; Slotboom, D.J. A mycobacterial $\mathrm{ABC}$ transporter mediates the uptake of hydrophilic compounds. Nature 2020, 580, 409-412. [CrossRef]

36. Nöll, A.; Thomas, C.; Herbring, V.; Zollmann, T.; Barth, K.; Mehdipour, A.R.; Tomasiak, T.M.; Brüchert, S.; Joseph, B.; Abele, R.; et al. Crystal structure and mechanistic basis of a functional homolog of the antigen transporter tap. Proc. Natl. Acad. Sci. USA 2017, 114, E438-E447. [CrossRef]

37. Thurlow, L.R.; Thomas, V.C.; Hancock, L.E. Capsular polysaccharide production in Enterococcus faecalis and contribution of cpsf to capsule serospecificity. J. Bacteriol. 2009, 191, 6203-6210. [CrossRef] [PubMed]

38. Trieu-Cuot, P.; Carlier, C.; Poyart-Salmeron, C.; Courvalin, P. Shuttle vectors containing a multiple cloning site and a lacz $\alpha$ gene for conjugal transfer of DNA from Escherichia coli to gram-positive bacteria. Gene 1991, 102, 99-104. [CrossRef]

39. Coelho, M.L.V.; Coutinho, B.G.; Cabral da Silva Santos, O.; Nes, I.F.; Bastos, M.d.C.d.F. Immunity to the Staphylococcus aureus leaderless four-peptide bacteriocin aureocin a70 is conferred by auri, an integral membrane protein. Res. Microbiol. 2014, 165, 50-59. [CrossRef] [PubMed]

40. Iwatani, S.; Yoneyama, F.; Miyashita, S.; Zendo, T.; Nakayama, J.; Sonomoto, K. Identification of the genes involved in the secretion and self-immunity of lacticin q, an unmodified leaderless bacteriocin from Lactococcus lactis qu 5. Microbiology 2012, 158, 2927-2935. [CrossRef] [PubMed]

41. Iwatani, S.; Horikiri, Y.; Zendo, T.; Nakayama, J.; Sonomoto, K. Bifunctional gene cluster lnqbcdef mediates bacteriocin production and immunity with differential genetic requirements. Appl. Environ. Microbiol. 2013, 79, 2446-2449. [CrossRef]

42. Blomberg, N.; Baraldi, E.; Nilges, M.; Saraste, M. The PH superfold: A structural scaffold for multiple functions. Trends Biochem. Sci. 1999, 24, 441-445. [CrossRef]

43. Lemmon, M.A. Pleckstrin homology (PH) domains. In Handbook of Cell Signaling; Bradshaw, R.A., Dennis, E.A., Eds.; Academic Press: Cambridge, MA, USA, 2010.

44. Abriouel, H.; Valdivia, E.; Martınez-Bueno, M.; Maqueda, M.; Gálvez, A. A simple method for semi-preparative-scale production and recovery of enterocin as-48 derived from Enterococcus faecalis subsp. liquefaciens a-48-32. J. Microbiol. Methods 2003, 55, 599-605. [CrossRef]

45. Krogh, A.; Larsson, B.; von Heijne, G.; Sonnhammer, E.L.L. Predicting transmembrane protein topology with a hidden markov model: Application to complete genomes11 edited by f. Cohen. J. Mol. Biol. 2001, 305, 567-580. [CrossRef] [PubMed] 